\title{
10: $104587168-104580284$
}

National Cancer Institute

\section{Source}

National Cancer Institute. 10:104587168-104580284. NCI Thesaurus. Code C42099.

Physical location of CYP17A1_Gene 